\title{
Evaluation of Intracanal Post Removal Using Ultrasound
}

\author{
Marlete Ribeiro da SILVA \\ João Carlos Gabrielli BIFFI \\ Adérito Soares da MOTA \\ Alfredo Júlio FERNANDES NETO \\ Flávio Domingues das NEVES
}

Department of Prostodontics, Faculty of Dentistry, Federal University of Uberlândia, Uberlândia, MG, Brazil

\begin{abstract}
The aim of this study was to determine the effect of ultrasonic vibration on the force necessary to remove pre-fabricated and anatomic and cast posts. Two hundred and forty teeth were divided into two groups. In group I, a $0.8-\mathrm{mm}$ metallic pre-fabricated post, UnimetricMaillefer, was utilized; in group II, cast copper-aluminum alloy posts measuring $0.8,1.0$ and $1.2 \mathrm{~mm}$ in diameter were used. The root canals were prepared in three different diameters: $0.8,1.0$ and $1.2 \mathrm{~mm}$, with a length of $10 \mathrm{~mm}$. The posts were cemented with glass monomer cement resulting in 20 specimens for each subgroup. Half of the sample was submitted to ultrasonic vibration for 3 min, while the other half did not receive any vibration. The specimens were submitted to traction in a universal testing machine. The results were analyzed by non-parametric Mann-Whitney U, Wilcoxon and Kruskal-Wallis tests. The application of ultrasonic vibration significantly reduced the retention provided by the glass ionomer cement in the fixation of intracanal posts. The ultrasonic action was effective in both pre-fabricated and anatomic and cast posts. The effectiveness of the ultrasonic vibration was not related to the cementation line or the diameter of the post.
\end{abstract}

Key Words: cementation, post removal, ultrasonic

\section{INTRODUCTION}

When indicating the usage of a post system, the possibility of its removal is seldom, if ever, considered. However, in practice, this can occur with risk of inherent weakening, perforation or dental remnant fracture (1). Some authors have suggested the use of an ultrasonic apparatus for this removal, either alone or in combination with other devices (1-7), justifying its usage due to the conservation of the dental structure and the reduction of other root damage. The ultrasonic vibration directs its action to the cementing agent, causing micro-fractures and consequently dislodging the post.

Buoncristiani et al. (4) compared the efficacy of ultrasonic and sonic vibration for the removal of 50 prefabricated stainless steel posts, in an intracanal $4 \mathrm{~mm}$ in length. The teeth were submitted, concomitantly, to vibration and traction. Working with 30 single-rooted teeth, Berbert et al. (1) studied the effect of ultrasonic vibration on the removal of intracanal cast posts, cemented with zinc phosphate, in an extension of $10 \mathrm{~mm}$. The force necessary to remove the posts was significantly lower for those submitted to ultrasound for 2 and 5 min compared to the group that received no treatment. Oliveira et al. (6) found similar results.

Johnson et al. (5) compared the force necessary to dislodge stainless steel posts cemented with zinc phosphate at a depth of $9 \mathrm{~mm}$ in extracted mandibular premolars, which were submitted to ultrasonic vibration for $0,4,12$, and $16 \mathrm{~min}$. The authors concluded that 16 min of ultrasonic vibration was significantly more effective than the other time periods for post removal.

A clinical study conducted by Smith (7) evaluated the efficacy of ultrasonic vibration in the removal of fractured posts in root canals. Thirty patients had ultrasonic vibration applied on the side of the fractured posts after a small furrow had been made around the 
fragment. A piezoelectric ultrasonic apparatus was utilized in order to apply vibration for two periods of $15 \mathrm{~s}$, and then for a period of $30 \mathrm{~s}$ until dislodgement of the post fragment. There was a significant statistical correlation between the length of the post fragment (approximately $3.8 \mathrm{~mm}$ ) and the ultrasonic vibration application time (average time of 2.05 minutes), but the correlation between the diameter and the ultrasound time was not significant.

Gomes et al. (8) evaluated ultrasound efficacy in the removal of cast posts in 84 single-rooted teeth cemented with zinc phosphate, glass ionomer and resinous cements, in a 10-min period. The application of ultrasonic vibration significantly reduced the retention by the zinc phosphate and glass ionomer cements in $39 \%$ and $33 \%$, respectively. The application of ultrasonic vibration did not influence the retention of cast posts cemented with composite. Matsumara et al. (9) reported similar results.

In spite of the scientific demonstration of the efficacy of the ultrasound for post removal, its action on pre-fabricated posts, compared to anatomic and cast posts, has not been well established. Thus, the present study purposed to evaluate, in vitro, the force necessary for the complete removal of posts when submitted to ultrasonic action, in circular standardized canals prepared to have apical intracanal diameters measuring $0.8,1.0$ and $1.2 \mathrm{~mm}$, using pre-fabricated posts with a $0.8-\mathrm{mm}$ apical diameter and anatomic and cast posts cemented with glass ionomer cement. This methodology allowed an evaluation of the influence of the post type, the cementation line and the post diameter on removal.

\section{MATERIAL AND METHODS}

Two hundred and forty teeth with circular canals, from the Surgery and Periodontology Clinics from the Dentistry Course of the Universidade Federal de Uberlândia were maintained in $10 \%$ formol, buffered at $\mathrm{pH}$ 7.0. The teeth were sectioned at the cementoenamel level, with the help of a diamond disc under irrigation, in such a way as to remain a $15 \mathrm{~mm}$ long root fragment.

The step-back instrumentation technique was used (10). The root canal was filled with gutta-percha cones (Dentsply, Imp. Indústria e Comércio Ltda. Petrópolis, RJ) and Fill-canal cement (DG Ligas Odontológicas Ltda., Rio de Janeiro, RJ) by the lateral condensation technique. After endodontic treatment, the teeth were divided into two groups. In group I, a prefabricated post was utilized; in group II an anatomic and cast post was used. Each group was divided into 3 subgroups, each containing 40 teeth. Canals of subgroup A were standardized at $0.8 \mathrm{~mm}, \mathrm{~B}$ at $1.0 \mathrm{~mm}$ and $\mathrm{C}$ at $1.2 \mathrm{~mm}$. Within these subgroups, 20 teeth were the control group and 20 the experimental group (submitted to ultrasonic vibration). Widening of the canal was carried out with the 212 and 213 burs (Maillefer Instruments, Ballaigues, Switzerland), in the extension corresponding to the bur's active tip $(10 \mathrm{~mm})$. Subgroup A preparations $(0.8 \mathrm{~mm})$ were carried out with burs 212 , 213 reference 308. Subgroup B preparations $(1.0 \mathrm{~mm})$ were carried out with burs 212, 213 reference 310. Subgroup C preparations $(1.2 \mathrm{~mm})$ were carried out with burs 212, 213 reference 310, with an adapted tip.

For group I, a UNIMETRIC 215 T post (titanium alloy) (no. 308; Maillefer Instruments) was used, having a conic form and serrated walls. For group II, copper-aluminum alloy anatomic and cast posts were utilized (Duracast MS, São Paulo, SP), with 0.8, 1.0 and $1.2 \mathrm{~mm}$ diameters in the end. The teeth were fixed with a chemically cured acrylic resin (Policron; Dencril Comércio e Indústria de Plástico Ltda., Caieiras, SP) to a stainless steel cylinder $(15 \mathrm{~mm}$ in diameter, $20 \mathrm{~mm}$ in height) in order to later accommodate the traction system. Fuji I (GC America, Alsip, IL) glass ionomer cement was used for cementation, mixed according to manufacturer instructions, being applied to the prepared canal (aided by an insertion Centrix syringe) and to the post. After its positioning, a 5-kg force was applied to the occlusal surface, following the long axis of the root's remnant for $7 \mathrm{~min}$, with the help of a load application apparatus. After $15 \mathrm{~min}$, each specimen was maintained in its container, with $100 \%$ relative humidity.

Ultrasonic vibration was applied to the posts

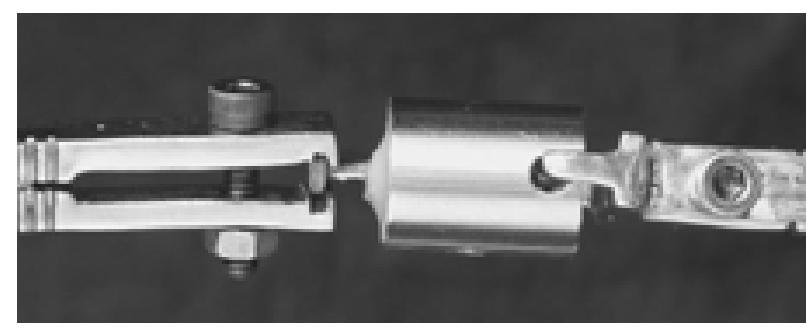

Figure 1. System utilized to adapt the fixture of the test machine to the specimen. 
with an Enac apparatus (Osada Eletric Co. Ltda., Tokyo, Japan) $72 \mathrm{~h}$ after cementation. The device was used at its greatest intensity with water spray, as recommended by the manufacturer. The tip was positioned on the occlusal, buccal and lingual surfaces for $1 \mathrm{~min}$ each and traction tests were carried out in the universal testing machine MEM - 2000 (Emic - Equipamentos e Sistemas de Ensaio Ltda.). A 1-min displacement speed was used. In order to use the equipment, a 200-kg load cell was adapted to the universal machine aiming to apply the force to the coronary portion of the post (Figure 1).

The results were analyzed by the non-parametric Mann-Whitney U, Wilcoxon and Kruskal-Wallis tests.

\section{RESULTS}

The results of the traction tests are illustrated in Figures 2-5. The force necessary for the removal of prefabricated and anatomic and cast posts cemented with glass ionomer was significantly reduced when ultra- sonic vibration was applied (Mann-Whitney U test).

Significant differences within groups were found only within the control group, with the highest values in the three cases obtained for the pre-fabricated posts. No correlation was found between ultrasonic vibration and the cement line, or for the diameter of the post.

\section{DISCUSSION}

The ultrasonic apparatus has clinical applications not only in providing vibration, but also in the instrumentation and cleaning of the root canal. This apparatus is also useful in the conservative removal of casted restorations and intracanal posts, separately or in combination with other techniques (1-3,5); however, scientific evidence is limited in evaluating the method. In a study by Buoncristiani et al. (4), posts with only a $4 \mathrm{~mm}$ extension were submitted to a constant traction force during the experiment. The average time required for the removal of posts was 6 min for the Cavitron Cavi-Endo, $8.3 \mathrm{~min}$ for the Enac, and $41.2 \mathrm{~min}$ for the

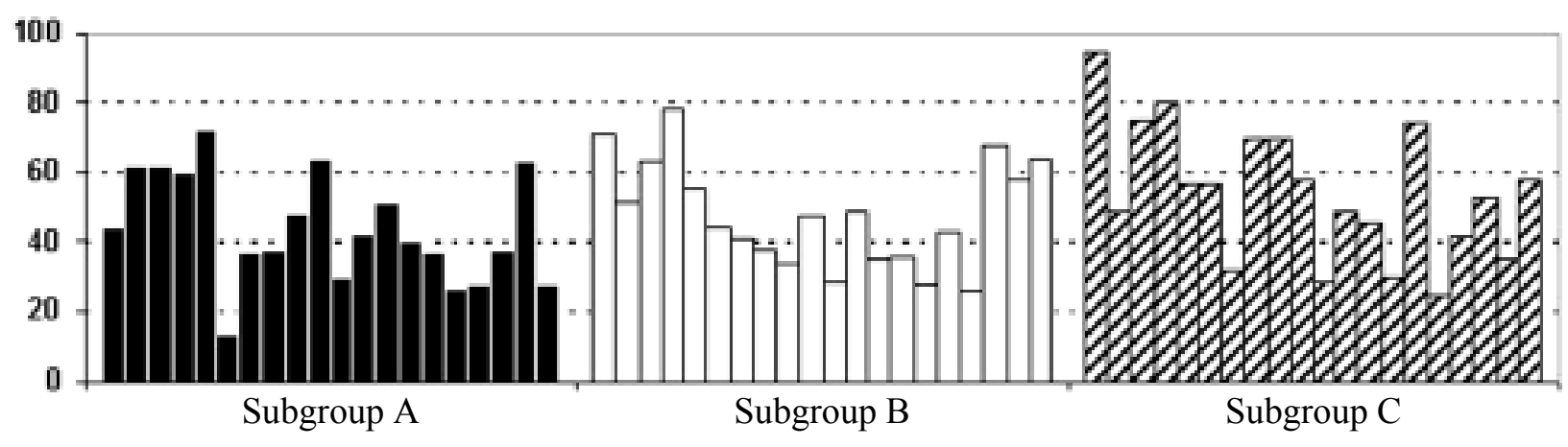

Figure 2. Traction test results for group I (pre-fabricated posts), with values expressed in $\mathrm{kg}$.

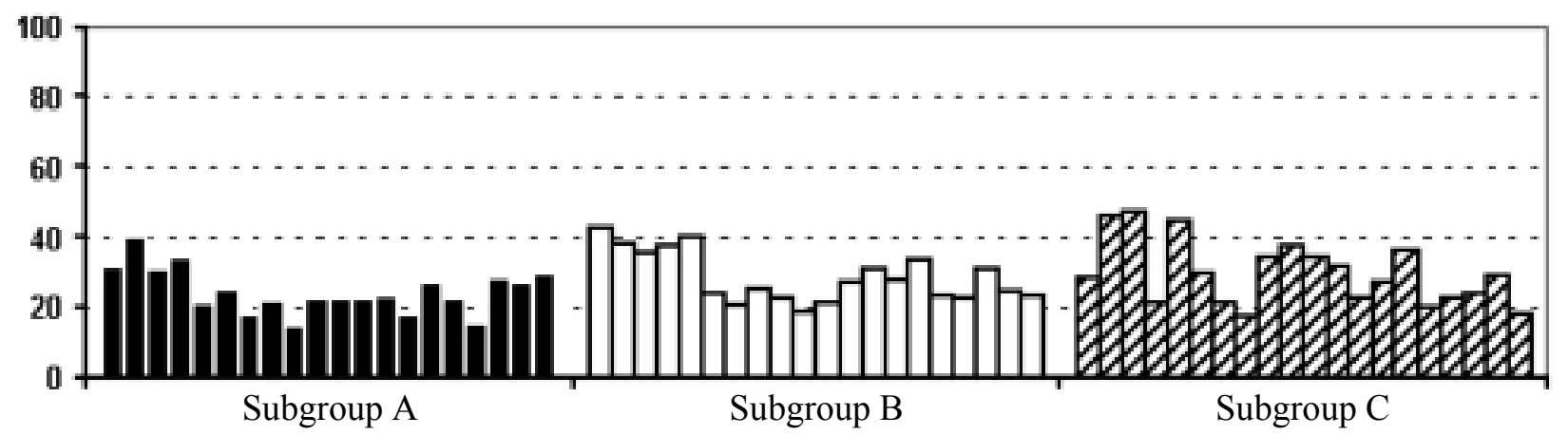

Figure 3. Traction test results for group II (anatomic and cast posts), with values expressed in $\mathrm{kg}$. 
Neosonic ultrasonic units.

According to Johnson et al. (5), the application of a constant traction force to the posts concurrently with ultrasonic vibration applied to the cement, which unites post and dentin, is not trustworthy; however, this procedure is recommended by Bergeron et al. (11).

The ultrasonic unit can be magnetostrictive, with electromagnetic energy being converted to mechanical energy (Cavi-Endo, Dentsply Intl., Inc., York, PA) or piezoeletric, the deformation of a crystal is converted to mechanical oscillations (Enac, Osada Electric Co.). Sonic devices work with air pressure (5). The Enac apparatus uses a piezoeletric mechanism, which vibrates at $30,000 \mathrm{~Hz}$, while the Cavi-Endo uses a magnetostrictive device which vibrates at $25,000 \mathrm{~Hz}$. The Neosonic piezoeletric ultrasound (Amadent, Cherry Hill, NJ), in spite of having a $35,000 \mathrm{~Hz}$ frequency, is not as rapid in post removal (4). According to the author, it is possible that the frequency or amplitude of the vibrations may be a key factor in post removal. The amplitude of the vibrations and their effect on the ability of the apparatus to remove posts is not well known. Some ultrasonic units may be able to increase their power in order to compensate the load increase in its tip. Many variables related to the operatory technique may influence the ability of the ultrasonic apparatus to remove cemented posts, not allowing any conclusion to be drawn from these variables.

Luting agents, including zinc phosphate, polycarboxylate, glass ionomer, and resinous cements, have been investigated extensively. Chan et al. (12) did not find significant differences when the intracanal posts (pre-fabricated or casted) were cemented with zinc phosphate and glass ionomer cements. These results were different from those obtained by Gomes et al. (8), who compared zinc phosphate and glass ionomer cements without the application of ultrasonic vibration. They reported a statistical difference in relation to the retentive force, with the zinc phosphate cement having a significant advantage. Tjan et al. (13) also demonstrated that pre-fabricated posts cemented with glass ionomer had greater retention values than those ce-

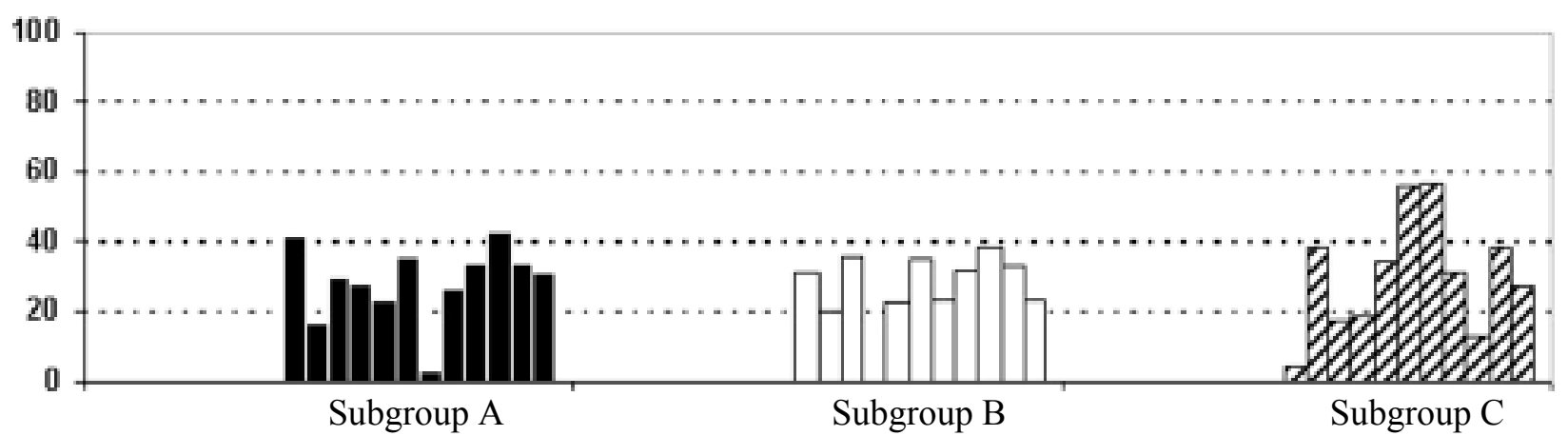

Figure 4. Traction test results for group I (pre-fabricated posts), after ultrasonic vibration, with values expressed in $\mathrm{kg}$

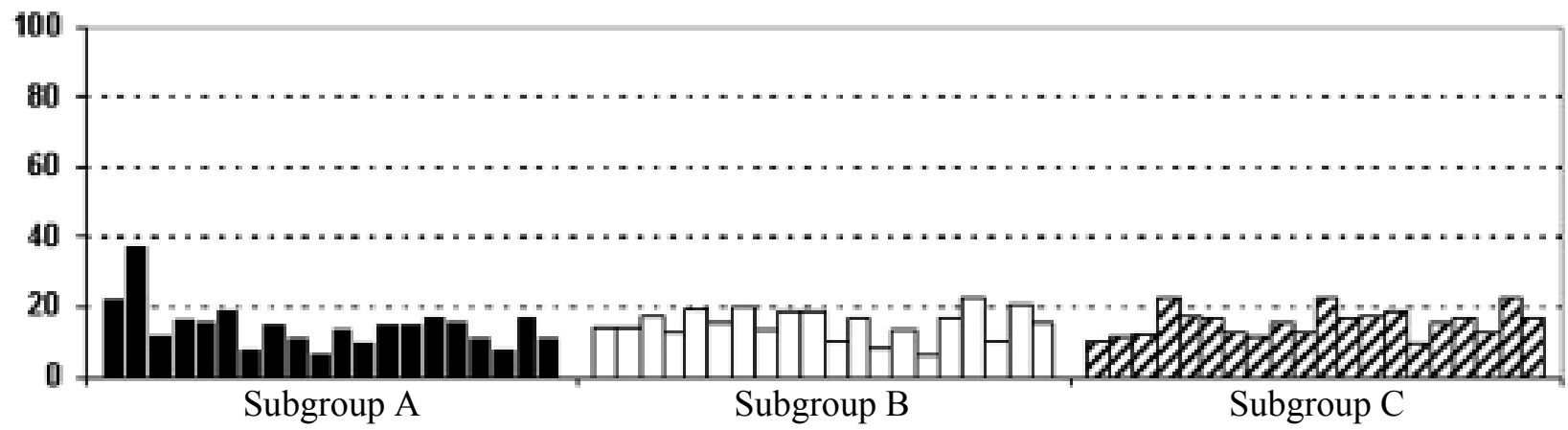

Figure 5. Traction test results for group II (anatomic and cast posts), after ultrasonic vibration, with values expressed in $\mathrm{kg}$ 
mented with zinc phosphate; however, not statistically significant. However, the authors previously treated the walls of the root canal with $1 \mathrm{ml}$ of $40 \%$ acrylic acid and then washed with distilled water before cementing the pre-fabricated posts with glass ionomer cement. Mota (14) also found retention values superior for the glass ionomer cement in relation to the zinc phosphate cement.

Bergeron et al. (11) did not find significant retention differences for posts cemented with zinc phosphate cement or Panavia 21. This suggests that the resistance to compression provided by different cements does not accurately predict its retentive abilities when they are used for post cementation. However, when comparing luting agents, Mendonza and Eakle (15) found that the glass ionomer cement Ketac-Cem offered the same or better retention than the resinous cement Panavia. Chan et al. (12) reported that posts cemented with resinous cement showed a significantly greater resistance to traction than zinc phosphate, glass ionomer and polycarboxylate cements. This confirms the finding that the increase in the resistance to compression of the cements produces an increase almost proportional in retention.

Chun and White (16) observed fractures as a response to compression tests with glass ionomers, without any measurable plastic deformation. This fact makes the ultrasonic method effective in the removal of posts cemented with these agents. On the other hand, the natural viscoelasticity of the resinous cements tends to annul the vibrations and absorbs the energy transmitted to the post. These cements are less brittle and may not have a tendency to microfractures as zinc phosphate and glass ionomer cements. This would explain the resistance to ultrasonic displacement $(4,8,9)$.

In relation to the time that the ultrasound was used to remove intracanal posts, the present study evaluated a period of $3 \mathrm{~min}$. This same time period was used with success by Oliveira et al. (6) for the removal of prefabricated posts cemented with zinc phosphate cement in a $10-\mathrm{mm}$ extension, with a post displacement from the canal of $67 \%$. Variations from 2 to $16 \mathrm{~min}$ $(1,4,5,8,17)$ in vibration time necessary to dislodge the post can be attributed to extension or experimental design differences.

During this experiment, an effort was made to maximize the energy transferal from the instrument tip to the post, adjusting the angle and the position of the tip in relation to the post. This was moved along the coronary portion of the post in order to find the best place or angle and was subjectively determined by the sound emitted by the post when the position was correctly adjusted. The end tip of the ultrasound was positioned in the occlusal and lateral aspects of the post, bilaterally, for a period of one minute in each side. Yoshida et al. (17) reports that the cement layer opposite to the ultrasound is destroyed before the one from the same side on which it had been placed. Transferring this reasoning to the present study, when the tip is positioned in three different directions, the cement breakage would occur apically and in two opposite lateral sides. In the study by Yoshida et al. (17), the ultrasonic vibration applied with two tips in opposing directions allowed cement layer destruction in the two sides simultaneously. That is, the usage of ultrasonic vibration in two opposite directions through two tips can make possible a rapid breakage of the bilateral cement layer, reducing the removal time. In single rooted teeth, a quicker post removal due to a smaller cement layer adhesion area is possible.

Visual post inspection after removal revealed that the control group failures occurred mainly in the cement-dentin interface. In the experimental group some fractures occurred in the cement. In spite of the cohesive fracture, the pre-fabricated posts presented a serrated external surface, bringing some retention between the cement and this surface. Buoncristiani et al. (4) also observed this type of cohesive failure in many of his specimens. While studying the ultrasonic mechanism of action on silver-palladium alloy posts, Yoshida et al. (17) reported that the ultrasonic vibration induced fracture propagation in the cement itself, and also separation of cement from the metallic cast. These findings were more evident than the cement separation from the dentin, suggesting that the resistance to ultrasonic vibration is smaller in the metal-cement interface than in the dentin-cement interface. The resistance to ultrasonic vibration seems to be influenced by the surface conditions of the substratum and the type of luting material.

Analysis of the results of this study revealed a statistically significant reduction in the force necessary for post removal when ultrasonic vibration was applied to the glass ionomer cement (Figures 4 and 5). In the control group, in which no ultrasound was used before traction, a greater resistance was obtained in the post 
removal (Figures 2 and 3). Theses results can be compared with those of other researchers $(1,4-6)$, who demonstrated efficiency of the ultrasonic device in the removal of posts cemented with zinc phosphate. The cement has an important role in this removal, since its rupture seems to be the mechanism of action of the ultrasonic vibration. Matsumura et al. (9) observed a $23 \%$ reduction in the glass ionomer retentive force, which united two nickel-chrome alloy disks after a 5min ultrasonic vibration. The anatomic and cast post retentive force reduction after ultrasonic vibration was also observed by Gomes et al. (8), when utilizing glass ionomer in the cementation. Likewise, the findings of the present study demonstrate that the use of ultrasonic vibration is an efficient technique when intracanal posts cemented with glass ionomer need to be removed, in a 10-mm extension.

One study using Parapost titanium posts, $1.5 \mathrm{~mm}$ in diameter and $9 \mathrm{~mm}$ intracanal, reported failure in post removal using ultrasonic vibration (11). The large extension and post stability were the hypotheses suggested by the authors for the failure, in spite of the cements used - zinc phosphate and Panavia 21. According to the authors, parallel posts can resist traction forces 4.5 times more than conic posts.

In the present study, ultrasound was an effective means of removal of both pre-fabricated and cast posts (Figures 4 and 5). Chan et al. (12) also found that post cementation to tight canals without ultrasound application did not necessarily offer greater post retention against vertical displacement forces, regardless of the cement type used. This tendency was observed when evaluating control groups A, B and C (Figures 2 and 3), where the pre-fabricated posts had higher retention values compared to the anatomic and cast posts. Contrarily, some studies recommend the use of well fitted posts, suggesting that they are more resistant to dislodging as confirmed by Colley et al. (18), who observed that the retention of posts was decreased when the cement thickness was increased.

Some hypotheses can be suggested for the absence of difference between the two post types, in terms of the ultrasonic action:

a) The hydrodynamic forces present during post insertion well fitted to the canals can modify the curing structure of the cement, altering its retentive properties. Since the opening between the post and canal wall decreases the cement line thickness, it becomes more difficult to produce a homogeneous cement layer (12). According Jorgensen (19) and Dimashkieh et al. (20), a filtration process occurs in the zinc phosphate cement during the cementation of well adapted crowns to the dental preparations. When the cement passage is reduced and large cement powder starts to cluster, the cement liquid filtrates, resulting in an unequal cement powder distribution within the phosphate matrix. This "filtration phenomenon" results in cement with inferior properties. The occurrence of similar modifications in the other cement types is possible.

b) The small space between a well fitted post and the canal wall can hinder escape of excess air and cement from the canal, preventing the post from being evenly covered with cement within the canal.

c) The pre-fabricated posts selected for this study were made with titanium alloy; the cast posts with $\mathrm{Cu}$ Al. According to Buoncristiani et al. (4), rigid materials with high elasticity module tend to conduct vibrations better. A material like titanium that has a smaller elasticity module than stainless steel would tend to conduct vibrations in a less efficient manner. This could result in either a longer instrumentation period or in high energy required to remove posts of this material.

d) The existence of an external serrated surface in the pre-fabricated post increases the surface area, working as mechanical retention for the cement. This result was observed by Colley et al. (18) whose study suggests that the serrated surface increases the metallic post retention.

A combination of these factors may have altered the efficacy of the ultrasonic technique in the prefabricated posts, not statistically distinguishing them from the cast posts, being this one better fitted and with a smaller cement line.

The root canals were standardized at $0.8,1.0$, and $1.2 \mathrm{~mm}$ diameters (subgroups $\mathrm{A}, \mathrm{B}, \mathrm{C}$, respectively). Pre-fabricated posts having a $0.8 \mathrm{~mm}$ apical diameter were used, offering a difference of $0.0,0.2$ and $0.4 \mathrm{~mm}$, respectively. This allowed an evaluation of the influence of the cement line on post retention and ultrasonic action. In the anatomic and cast posts, the root canal standardization allowed an evaluation of the post diameter and its relation to retention and ultrasound. In this manner, the methodology used made the verification of the ultrasonic action possible, while varying post diameter, as in the case of anatomic and cast posts - subgroups $\mathrm{A}, \mathrm{B}$ and $\mathrm{C}$ - and the cement line 
thickness, as in the case of pre-fabricated posts, since the dimensions of these were constant for all specimens. Statistical differences were not found between the comparisons carried out, which means that in the pre-fabricated posts the cement line variation did not influence the ultrasonic action (Figure 4). These results are in disagreement with Colley et al. (18), in relation to post retention without the application of ultrasonic vibration, who considers the cement film thickness as a retentive factor, that is, as thickness decreases, retention increases.

For the anatomic and cast posts, a significant statistical correlation was not found between the ultrasonic vibration efficacy and the post diameter (Figure 5). Smith (7) found similar results, reporting that ultrasonic vibration is related to a surface area involving the post. A possible alternative is that, under vibration, the cement is fragmented sequentially, starting from an area close to the tip toward the apical direction, until the post is dislodged. The ultrasound time tends, therefore, to be more related to post extension than to its diameter. Lack of differences in retention between posts with different diameters suggests that it is unnecessary to widen the canal in order to allow the placement of a wider post. Wider, well fitted posts can weaken and induce stress to the tooth, resulting in fractures.

We conclude that 1) Ultrasonic vibration application reduced the retention offered by the glass ionomer cement in the intracanal post fixation. 2) Cementation of well fitted posts to root canals did not necessarily offer a greater retention against displacement provided by a vertical traction force, both in the control and experimental groups. The ultrasonic action was effective both in the pre-fabricated and anatomic and cast posts. 3) Ultrasonic vibration efficacy was not related to the cement line, nor to the post diameter.

\section{RESUMO}

O objetivo deste estudo foi determinar o efeito da vibração ultrasônica na força necessária para a remoção de pinos pré-fabricados e moldados e fundidos. Foram utilizados 120 dentes, divididos em dois grupos. No grupo I foi utilizado o pino pré-fabricado metálico, Unimetric-Maillefer, de $0,8 \mathrm{~mm}$; no grupo II foi utilizado o pino em liga de cobre-alumínio com $0,8,1,0$ e $1,2 \mathrm{~mm}$ de diâmetro. Os canais radiculares foram preparados com três diferentes diâmetros: 0,8, 1,0 e 1,2 mm, e com $10 \mathrm{~mm}$ em extensão. Os pinos foram fixados com cimento ionômero de vidro, resultando em 20 espécimes para cada subgrupo. Metade da amostra foi submetida à vibração ultra-sônica durante três minutos, enquanto a outra metade não recebeu nenhuma vibração. Os espécimes foram submetidos a uma carga de tração axial em uma máquina de testes universal. Os resultados foram analisados por testes não-paramétricos: U de Mann-Whitney, Wilcoxon e Kruskal-Wallis. A aplicação da vibração ultra-sônica reduziu significativamente a retenção promovida pelo cimento ionômero de vidro na fixação dos pinos intra-radiculares. A ação ultrasônica foi efetiva tanto nos pinos pré-fabricados como nos pinos moldados e fundidos. A efetividade da vibração ultra-sônica não foi relacionada à linha de cimentação ou ao diâmetro do pino.

\section{ACKNOWLEDGMENTS}

The authors would like to thank Ricardo Souza Antunes, Edson Volta, Paulo César Simamoto Júnior, and Gustavo Mendonça for their contributions during the development of this work.

\section{REFERENCES}

1. Berbert A, Filho MT, Ueno AH, Bramante CM, Ishikiriama A. The influence of ultrasound in removing intrarradicular posts. Int Endod J 1995;28:54-56.

2. Gaffney JL, Lehman JW, Miles MJ. Expanded use of the ultrasonic scaler. J Endod 1981;7:228-229.

3. Krell KV, Jordan RD, Madison S, Aquilino S. Using ultrasonic scalers to remove fractured root posts. J Prosthet Dent 1986;55:46-49.

4. Buoncristiani I, Seto BG, Caputo AA. Evaluation of ultrasonic and sonic instruments for intraradicular post removal. J Endod 1994;20:486-489.

5. Johnson WT, Leary JM, Boyer DB. Effect of vibration on post removal in extracted human premolar teeth. J Endod 1996;22:487-488.

6. Oliveira MRS, Biffi JCG, Mota AS, Maniglia CAG. Avaliação da remoção de pinos intra-radiculares pré-fabricados através de técnica ultra-sônica. Rev Assoc Paul Cir Dent 1999;53:372-377.

7. Smith BLJ. Removal of fractured posts using ultrasonic vibration: an in vivo study. J Prosthet Dent 2001;27:632-634.

8. Gomes APM, Kubo CH, Santos RAB, Santos DR, Padilha RQ. The influence of ultrasound on the retention of cast posts cemented with different agents. Int Endod J 2001;34:93-99.

9. Matsumura H, Salonga JP, Yohsuke T, Atsuta M. Effect of ultrasonic instrumentation on bond strength of three dental cements bonded to nickel-chromium alloy. J Prosthet Dent 1996;75:309-313.

10. Leonardo MR, Leal JM. Endodontia - Tratamento de canais radiculares. 2nd edn. São Paulo: Editora Médica Panamericana; 1992.

11. Bergeron BE, Murchison DF, Schindler WG, Walker WA. Effect of ultrasonic vibration and various sealer and cement combinations on titanium post removal. J Endod 2001;27:13-17.

12. Chan FW, Harcourt JK, Brockhurst PJ. The effect of post adaptation in the root canal on retention of posts cemented with various cements. Aust Dent J 1993;38:39-45.

13. Tjan AHL, Tjan AH, Greive JH. Effects of various cementation methods on the retention of prefabricated posts. J Prosthet Dent 1987;58:309-313.

14. Mota AS. Estudo comparativo da força de tração entre os pinos pré-fabricados e moldados e fundidos após a cimentação com fosfato de zinco e ionômero de vidro em canais radiculares 
previamente estandardizados. (Doctorate thesis). Ribeirão Preto: Universidade de São Paulo; 2002. 119 p.

15. Mendonza DB, Eakle S. Retention of posts cemented with various dentinal bonding cements. J Prosthet Dent 1994;72:591-594.

16. Chun ZL, White SN. Mechanical properties of dental luting cements. J Prosthet Dent 1999;81:597-609.

17. Yoshida T, Gomyo S, Itoh T, Shibata T, Sekine I. An experimental study of the removal of cemented dowel-retained cast cores by ultrasonic vibration. J Endod 1997;23:239-241.
18. Colley IT, Hampson EL, Lehman ML. Retention of post crowns: an assessment of the relative efficiency of posts of difficult shapes and sizes. Brit Dent J 1968;124:63-69.

19. Jorgensen K. Relationship between retention and convergence angle in cemented veneer crowns. Act Odontol Scandin 1955;13:35-40.

20. Dimashkieh MR, Davies EH, Fraunhofer JA. Measurement of the cement film thickness beneath full crown restorations. Br Dent J 1974;137:281-284. 